Boise State University

ScholarWorks

Public Policy and Administration Faculty

Publications and Presentations

Department of Public Policy and Administration

4-2019

\title{
Obstacles and Motivators for Partnership Formation in a Multi- Dimensional Environment
}

Luke Fowler

Boise State University

This is the peer reviewed version of the following article:

Fowler, Luke. (2019). Obstacles and Motivators for Partnership Formation in a Multidimensional Environment. P\&P:

Politics \& Policy, 47(2), 267-299. doi: 10.1111/polp.12293

This article may be used for non-commercial purposes in accordance with Wiley Terms and Conditions for SelfArchiving. 
This is an author-produced, peer-reviewed version of this article. The final, definitive version of this document can be found online at Journal

for Critical Education Policy Studies, published by the Institute for Education Policy Studies. Copyright restrictions may apply.

\title{
Obstacles and Motivators for Partnership Formation in a Multi-Dimensional Environment
}

\author{
Luke Fowler \\ School of Public Service \\ Boise State University
}

\begin{abstract}
Partnerships are now essential to public service delivery. However, due to limitations in collaborative capacity, there are both obstacles and motivators for forming partnerships. Intergovernmental and cross-sectoral partnerships offer different advantages and disadvantages in extending public service missions in new directions. Using survey data of local air quality agencies, findings determine different factors contribute to partnership and non-partnership. Further findings suggest partnerships are driven largely by problem severity, but non-partnership is driven by specific benefits and risks associated with types of partners. Conclusions indicate that understanding non-partnership is a key to understanding partnership formation.
\end{abstract}

Keywords: collaboration, non-collaboration, intergovernmental partnership, public-private partnership, publicnonprofit partnership, local government, air quality, environmental policy

\section{Introduction}

Partnerships are an integral part of public service delivery, as policy implementation now requires cooperation between levels of government and economic sectors to be successful. Extant research identifies several key factors in making partnerships work, including issues related to inter-personal relations, network structures, institutional arrangements, and measuring outcomes (Provan and Milward 2001; McQuaid 2010). However, according to Andrews and Entwistle (2010), "scant attention has yet been paid to the key strategic questions of what kinds of organizations are best to partner with" (p. 679). In the United States (U.S.), potential partners exist in a multi-dimensional environment that includes both vertical and horizontal intergovernmental as well as cross-sectoral ties, with each type of partner offering unique advantages and disadvantages by extending public service operations in new directions. Notably, some organizations are better suited for partnerships than others, depending on goals and organizational needs. Consequently, the calculus of partnership formation is complex, involving a balance of both potential benefits and risks.

Given that public-sector organizations cannot reasonably collaborate with everyone, obstacles and motivators to partnership formation exist. While some scholarship explores factors correlated with partnerships (Graddy and Chen 2006; Fowler 2018), there are fewer insights into organizational constraints that create obstacles to cooperative ties. More specifically, extant research tends to focus on why partners form, but rarely consider why partnerships fail to come to fruition. Furthermore, lack of partnership tends to be seen in a negative light (i.e., collaboration is the goal) (Kettl 2006), but in some cases, partnerships can hinder organizational performance, especially if organizations are not well-suited as partners and/or lack requisite capacities to manage shared problems (Longoria 2005; Hodge and Greve 2007). Since not partnering occurs by default for most organizations, the barriers to collaboration can provide important insights into why managers avoid partnerships or what factors contribute to a heightened perception of risks involved. In other words, understanding why partnerships fail to form is an important piece of the puzzle of understanding inter-organizational relationships during the modern era of governance.

In light of these issues, we examine how factors such as problem severity, available resources, equity, autonomy, and competitiveness motivate or hinder inter-organizational ties with specific types of partners. In exploring partnership motivators and obstacles, first, we review literature on partnerships in the public sector and compare multi-dimensional types of partners. Then, we examine partnerships based on data from a sampling of local air agencies. Findings indicate that local agencies partner or do not partner with types of organizations for different reasons, which is likely 
This is an author-produced, peer-reviewed version of this article. The final, definitive version of this document can be found online at Journal for Critical Education Policy Studies, published by the Institute for Education Policy Studies. Copyright restrictions may apply.

to their benefit as certain types of organizations represent more risk than reward. Results of a statistical analysis indicate partnerships are driven primarily by problem severity, but non-partnerships are driven by specific benefits and risks associated with types of partners. Finally, we offer conclusions on partnership and non-partnership.

\section{Cooperation Complexities}

Understanding when cooperation occurs is a long-standing pursuit of academics across many disciplines, including public policy and administration, political science, economics, and even biology, with Ostrom's (2015) work on governing common pool resources as an illustration of its interdisciplinary importance (Axelrod 2006). However, few comprehensive answers are available, other than cooperation "occurs when the pursuit of self-interest by each leads to a poor outcome for all” (Axelrod 2006, p. 7). In particular, public-sector organizations may be limited in addressing some complex policy problems but share goals with organizations from other jurisdictions and/or economic sectors. To that end, public administration network scholarship focuses heavily on how inter-organizational ties (i.e., connections between organizations) that deviate from bureaucracies or markets can facilitate collective action when single organizations cannot achieve policy goals (Agranoff and McGuire 2001; Koliba, Mills, and Zia 2011; O'Toole 2015). Additionally, contemporary theoretical frameworks for policy implementation and public-service delivery are grounded in network theory and include inter-organizational ties, cooperative behavior, government and nongovernmental actors, and assumptions that do not apply to conventional hierarchical, bureaucratic, or market arrangements (Provan and Milward 2001; Lundin 2007; Hill and Hupe 2014; O’Toole 2015; Fowler 2018).

As such, cooperative ties are an important factor in program success and take on many different forms, ranging from service contracts to "joining up" public service delivery (Andrews and Entwistle 2010). While we do not draw these distinctions, there is some scholarship that disambiguates cooperation, collaboration, and partnerships by identifying collaboration as a higher-order form of collective action compared to cooperation as a lower-order form and partnerships as formalized agreements (Thomson and Perry 2006). Others argue differences depend on organizational integration, which ranges from contracting out and government-driven goal specification to partnering and joint platforms for defining goals (Teisman and Klijn 2002). Common points of comparison in this scholarship center on purposes related to shared policy goals, with different partnership forms offering both advantages and disadvantages based on strategic focus, missions, resources, and capacities (McQuaid 2010). Although some typologies capture nuances of multi-dimensional ties, there are few comprehensive comparisons of partnerships relative to organizational types (Johnson 2014; Morris and Miller-Stevens 2015).

Furthermore, current scholarship only tends to focus on organizations already collaborating with others, and not those organizations that have failed to form such inter-organizational ties. A key component of this is that measuring and evaluating partnerships is not an easy task. Their practical and informal nature creates many methodological barriers for identification and comparison across diverse organizations functioning in unique contexts (Hodge and Greve 2007; Isett, Mergel, LeRoux, Mischen, and Rethemeyer 2011; O’Toole 2015). By extension, examining partnership that do not come to fruition is an even more difficult task. Consequently, there is a dearth of scholarship explaining why noncooperation persists. As scholarship frames collaboration and partnership as a managerial tool to overcome complex policy problems in the face of limited organizational capacities, there is only limited consideration of non-cooperation as a managerial tool as well. More specifically, managers may also be using non-cooperation to maintain organizational autonomy, avoid risk, or minimize transaction costs in service delivery (Provan and Milward 2001; Agranoff 2006; McGuire and Agranoff 2011). As such, examining non-cooperation can provide important insights into why partnerships fail to form even when need and opportunity exist (Fowler 2018).

\section{Complex Partnership Choices}

There are two interrelated sides to partnership formation: why they occur and why they do not occur. Partnership requires some form of active engagement in collaboration or cooperation, and consequently, requires active choices to engage other organizations (i.e., organizations do not end up in partnerships by default) (Thomson and Perry 2006). On the other hand, non-partnership can be either active where managers purposefully do not engage other organizations, or passive (i.e., occur by default) where managers simply do not pursue engagement. Since scholarship normally assumes that partnership does not occur without specific catalysts and non-partnership is a default with no specific explanation, it focuses heavily on the former with little or no investigation of the latter. Nevertheless, both components are important in understanding what mechanisms reinforce default positions of non-partnerships or create 
This is an author-produced, peer-reviewed version of this article. The final, definitive version of this document can be found online at Journal for Critical Education Policy Studies, published by the Institute for Education Policy Studies. Copyright restrictions may apply.

specific catalyst for change that leads to partnership formation. In other words, if partnership formation is a function of both passive and active action, then explanations that account for non-partnering can also explain why collaboration do not come to fruition.

Both active and passive mechanisms surrounding partnership and non-partnership maybe proactive or reactive and are responsive to both internal and external organizational stresses, where managers weigh risks and rewards associated with specific partnership opportunities (Grady and Chen 2006; Fowler 2018). In most cases, nonpartnership is both the starting position and the far more likely ending position, because it does not require action. Furthermore, partnership requires motivations for joint action, while non-partnership can occur in spite of motivation to joint action if sufficient obstacles exist. While theoretically (and for analytical purposes) these constructs can be separated, in practice they likely occur concurrently, where managers must decide to challenge existing status quos (i.e., non-partnering) and to adopt a new status quo (i.e., partnering). Reversion to non-partnership is a potential outcome in either stage. Additionally, following a shift from non-partnering to partnering, managers must also consider levels of integration specific partnerships might involve (i.e., simple coordination or full operational integration). As such, partnership formation is a multi-stage process that is difficult to separate in practice. Nevertheless, scholarship tends to focus only on latter stages of that process, so creating an analytical separation allows for a more nuanced analysis.

\section{$\underline{\text { Motivations and Obstacles }}$}

Previous scholarship suggests that public-sector organizations partner for two reasons: internal pressures and external opportunities. Obtaining resources to support internal programmatic needs or shared policy goals are the most commonly identified internal motivations for partnerships (Fowler 2018). Organizations will collaborate with others sharing a policy goal if they believe they can gain resources (either tangible or intangible) in the process (Graddy and Chen 2006; Lee, Lee, and Feiock 2012; Provan and Huang 2012; Park and Rethemeyer 2014; Fowler 2018). Commitments to goals, inter-organizational trust, problem severity, managerial capacity, organizational structure, and risk assessment are also important factors in willingness to cooperate with other organizations (Andrew 2009; Feiock, Lee, Park, and Lee 2010; McGuire and Silvia 2010; Bunger 2013; Fowler 2018). On the other hand, new organizations also consider external factors when entering a network such as network structure, size, scope, and experience; potential for partnerships; mandated inter-organizational ties or responsibilities; and perceived costs and benefits (O’Toole 1997, 2015; Graddy and Chen 2006; Fowler 2018). However, partnerships must form a balance that creates interorganizational ties but also allows for individual autonomy (Graddy and Chen 2006; Fischer, Ingold, Sciarini and Varone 2012; Lee, et al. 2012; O’Toole 2015; Fowler 2018).

Additionally, partnership formation faces many obstacles, and non-partnership is the default in most cases. Actors are constrained by their capacity to understand associated costs and benefits, forcing decisions with imperfect information (Smith and Larimer 2009). Exacerbated by the growing number of organizations providing public services since the 1980s, actors lack capacity to effectively consider or participate in partnerships with the myriad of potential organizations available (Hill and Hupe 2014). Moreover, there is an economy of scale to networks, where coordination costs eventually overburden transactions, reduce network effectiveness, and lead to collaborative inertia (Provan and Milward 2001; McGuire and Agranoff 2011; Provan and Lemaire 2012). Additionally, networks face "operational, performance, or legal barriers that prevent the next action step... [and] face challenges in converting solutions into policy energy, assessing internal effectiveness, surmounting the inevitable process blockages, mission drift, and so on” (McGuire and Agranoff 2011, p. 265). Thus, organizations must limit their partners to an elite few, based on their unique situation.

\section{Multi-Dimensional Partners}

In forming partnerships, managers are aware of both internal organizational needs and external opportunities and threats (Graddy and Chen 2016; Fowler 2018). As such, they seek to maximize benefits and minimize risks of partnership by matching with an organization with the highest capacity to fulfill their needs without creating an undue threat to organizational goals. While there is significant research through different theoretical frameworks on benefits of partnerships that indicate notable differences across organizational dimensions, scholarship is limited in integrating these findings to account for how organizational types fit different needs (Andrews and Entwistle 2010; Walker and Andrews 2013). To assess advantages and disadvantages offered by both intergovernmental and cross-sectoral partners, table 1 compares types of potential partner based on benefits via extending scopes of operations into new geographic, legal, or economic jurisdictions, and inherent risks associated with pre-existing institutional arrangements. 
This is an author-produced, peer-reviewed version of this article. The final, definitive version of this document can be found online at Journal for Critical Education Policy Studies, published by the Institute for Education Policy Studies. Copyright restrictions may apply.

Intergovernmental and cross-sectoral partnership both come in two forms: vertical (i.e., partners at different levels) and horizontal (i.e., partners at the same level); and, public-nonprofit and public-private. Intergovernmental partnerships increase effectiveness through an extension of operations into comprehensive or comparative jurisdictions, while cross-sectoral partnerships increase equity and/or efficiency by extending operations into either markets or areas of market failure. On the other hand, intergovernmental partnerships face barriers related to conscription of lower-level governments by higher-level governments and replacing competition with cooperation, while cross-sectoral partnerships suffer from principal-agent problems. Consequently, types of partners are not interchangeable and compatibility with public-sector organizations depends largely on specific environments in which they operate.

\section{[Table 1 about here]}

\section{Intergovernmental Partnerships}

Intergovernmental (public-public) are the most common form of public-sector partnership. Many public-sector organizations have fragmented authorities created by divisions in geographic and legal jurisdictions (Feiock and Scholtz 2009). As it is difficult for a single organization to effectively address a problem that is only partially within its jurisdiction, intergovernmental partnerships extend operations into new jurisdictions which better match complex problems (Thurmaier and Wood 2002; Raab and Milward 2003; Andrews and Entwistle 2010). As such, some federal programs mandate intergovernmental ties and require federal, state, and/or local agencies to work together on complex problems, which creates further complication in network management (O’Toole 1997). Nevertheless, expansion brings economies of scale and coordinated institutional arrangements, leading to more effective outcomes (Thurmaier and Wood 2002; Keast et al. 2004; Andrews and Entwistle 2010). Managers with severe policy problems or prohibitive performance demands are likely to reach out to other public agencies dealing with the same or similar issues in order to "join up" operations, and increase resources or capacity for managing a complex problem. Consequently, if public-sector organizations effectively achieve their missions, intergovernmental partnerships are unnecessary, but if they are ineffective or problems are severe, then there is motivation for collaboration with other public-sector organizations.

More specifically, vertical intergovernmental partnerships extend operations to include a more comprehensive institutional approach, presenting a large increase in operational scope. For example, in the U.S., State Rural Development Councils and the National Rural Development Partnership create a forum for all levels of government to collaborate for rural development, bringing in resources, expertise, and economic development networks that would otherwise be unavailable to rural local governments (Agranoff and McGuire 2001). However, with vertical partnerships, there is risk of power asymmetries that lead to conscription of lower-level partners into service by higherlevel partners, making them less like partnerships and more like hierarchies, especially when relationships are mandated (Scicchitano and Hedge 1993; Agranoff and McGuire 1999; Zimmerman 2009). For example, although the U.S. Resource Conservation and Recovery Act (RCRA) is ostensibly a federal-state partnership, federal agencies use statutory language, resources, compliance reporting, and sanctions to partially preempt state authority in the program (Scicchitano and Hedge 1993). Therefore, managers concerned that they would effectively become compliance managers because of partnership with federal (or state) agencies are likely to find alternative organizations to work with in order to preserve their autonomy, or not fully invest in these ties, even if mandated. Even though vertical partnerships increase effectiveness and reduce problem severity by creating a more comprehensive institutional approach to interjurisdictional problems, there is risk of losing autonomy. As such, loss of autonomy serves as a barrier to these partnerships, leading to non-partnership by default.

On the other hand, horizontal intergovernmental partners expand operations into comparative jurisdictions, with complementary missions, adjacent jurisdictions, or shared goals (Ling 2002; Warner and Bel 2008). These partnerships offer similar benefits of effectiveness as vertical partnerships, but at a smaller scale (Warner and Bel 2008). One of the most common examples is regional economic development, where collective resources are used to recruit new industries to an area benefiting all neighboring communities via spill-over effects (Gordon, 2007; Feiock, Steinacker, and Park 2009). However, it is difficult to replace competition with cooperation, due to institutional barriers, cultural norms, bargaining dynamics, and trust (Gordon, 2007; Feiock and Scholtz 2009; Kwon and Feiock 2010). For example, Gordon (2007) reports a culture of competition within regional economic development networks, where partners supposedly work together but also tend to revert to "game playing" and use tools such as zoning to affect site selection of specific projects recruited to a region through a cooperative effort. In general, when benefit sharing becomes inequitable between inter-local partners, they stop complying and devolve to competitive or self- 
This is an author-produced, peer-reviewed version of this article. The final, definitive version of this document can be found online at Journal for Critical Education Policy Studies, published by the Institute for Education Policy Studies. Copyright restrictions may apply.

interested behavior, resulting in a relationship breakdown (Bennett and Howe 1998; Chen and Thurmaier 2009). Consequently, local managers who do not trust other local agencies to cooperate faithfully are likely to avoid investing resources into a partnership agreement that they think will eventually collapse. Thus, horizontal partnerships offer effectiveness through expansion to comparative jurisdictions, but do not replace inter-local competition. Subsequently, potential for failed cooperation and lack of trust can outweigh benefits of horizontal partnerships, leading to non-partnership.

\section{Cross-Sectoral Partnerships}

Cross-sectoral partnerships expand public service missions into new economic segments that would otherwise be difficult to access for public-sector organizations. In particular, public-nonprofit partnerships have expanded in recent decades, as public sector limitations in serving underserved populations became more apparent (Alexander and Nank 2009). Nonprofits address market failures by filling gaps between public- and private-sectors via representing traditionally disadvantaged, excluded, or underrepresented groups (Andrews and Entwistle 2010). Without jurisdictional, political, and/or economic constraints that hamper public-sector organizations, nonprofits have a unique capacity to create equity and fairness by connecting with populations and problems that do not readily fit into conventional public-sector missions (Weisbrod 1997; Wallis and Dollery 2006; Andrews and Entwistle 2010). For example, West Harlem Environmental Action (WE ACT) in New York partnered with other local environmental health groups and the U.S. Environmental Protection Agency (EPA) to raise public awareness of pollutant health impacts among local minority communities, which ultimately lead to better health outcomes for a vulnerable population (Minkler, Vasquez, Tajik, and Petersen 2008). As such, managers with pressure (via community leaders or elected officials) to serve minority populations but without adequate capacity to do so are likely to seek out nonprofits as a means to expand their operations without stressing existing resources. As such, nonprofits attract public-sector partners in need of expanding services to under-privileged populations, but public-sector organizations not struggling with servicing those populations have little interest.

On the other hand, private-sector organizations "are better at performing economics tasks, innovating, replicating successful experiments, adapting to rapid change, abandoning unsuccessful or obsolete activities and performing complex or technical tasks" (Osborne and Gaebler 1992, p. 45-46). With extra-governmental resources and increased pressure for efficiency, private partners provide access to marketplace benefits, such as funds, expertise, flexibility, and shared risk (Cohen and Eimicke 2008; Andrews and Entwistle 2010). The most common examples are contracting out public services to private companies, such as a private firm collecting garbage under an agreement with a local government, where cost-savings result from increased operational flexibility and/or competition between private firms. Other forms include cooperation for joint production and risk sharing, long-term infrastructure development projects, policy networks, and community development (Hodge and Greve 2007). Managers with increased performance and financial demands from elected officials are likely to seek out partners that can offer access to extragovernmental resources and with more flexibility to provide services at reduced costs in order to improve performance without additional public resources. As such, public-private partnerships offer attractive benefits for public-sector organizations struggling with delivering services with limited resources.

Nevertheless, cross-sectoral partnerships suffer from classic principal-agent problems, where information asymmetries, goal incongruity, and mission differences lead to conflict. For example, private prisons produce operational cost-saving, but typically at the expense of prisoner well-being. As such, there is significant scrutiny of contracts that might provide public services below expected quality (Bedard and Frech 2009). Successes and failures of cross-sectoral partnerships tend to be explained by organizational capacities for managing incompatibilities and holding partners accountable (Skelcher 2005; Gazley and Brudney 2007; Hodge and Greve 2007; Acar, Guo, and Yang 2008). Managers wary of program or resource misuse or attracting heightened scrutiny from stakeholders concerned about conflicts of interest are likely to be unwilling to engage cross-sectoral partners. In sum, cross-sectoral partnerships offer equity and efficiency, respectively, but come with principal-agent problems.

\section{Managing Air Quality}

In the U.S., the Clean Air Act (CAA) of 1970 (amended in 1977 and 1990) relies on a federal-state partnership: EPA sets ambient air quality standards and provides oversight of state programs; and, states develop implementation plans (Belden 2001; Fowler 2016, 2018). Within this context, local air quality offers an adept case to examine partnership formation for several reasons. First, although hierarchical components exist, previous research argues CAA implementation functions more as a network with fluidity in membership and organizations mostly controlling their 
This is an author-produced, peer-reviewed version of this article. The final, definitive version of this document can be found online at Journal for Critical Education Policy Studies, published by the Institute for Education Policy Studies. Copyright restrictions may apply.

own engagement (Fowler 2018). Second, local responsibilities fluctuate between states, with some local governments operating as administrative sub-units of states, some having complete independence, and others having no role at all (Lester and Lombard 1998; Woods and Potoski 2010; Fowler 2016, 2018). However, due to limited jurisdictions, most local governments need to collaborate in order to affect air quality (Fowler 2016).

Third, competitive pressures have led to policy innovation at state and local-levels, which have included both new pollution control strategies and collaborative efforts (Woods and Potoski 2010; Fowler 2018). While federal regulations primarily focus on technology-forcing provisions for stationary (e.g., industrial sites) and mobile (e.g., cars) sources of air pollutants, state and local policies are more diverse and rely on different strategies (e.g., smart growth and energy planning) that align with local policy contexts. Fourth, there is a regional component created by Air Quality Control Regions (AQCRs), which tend to align with metropolitan areas (Belden 2001; Fowler 2016). Since pollutants transect jurisdictional boundaries and drift across geographic areas, this presents a ripe context for potential partnerships to form across jurisdictions. Finally, scholarship identifies several key factors for environmental policy that also impact collaborations, such as program effectiveness, problem severity, resource available, equity (i.e., environmental justice), and intergovernmental relations (Vig and Kraft 2016).

In practice, governing legislation and the nature of air quality encourages intergovernmental partnerships. For local governments, partnering directly with state and federal agencies typically means serving as a local arm of their implementation schemes (Lester and Lombard 1998; Woods and Potoski 2010; Fowler 2016, 2018). This provides additional access to resources, but severely limits autonomy and innovation capacity (Fowler 2018). However, state and federal air quality missions tend to be limited to area specific attainment of the National Ambient Air Quality Standards (NAAQS), and not universally improving air quality. Therefore, local areas not threatened with nonattainment get limited attention and resources from vertical intergovernmental partners. On the other hand, horizontal partnerships provide an opportunity "to coordinate projects and initiatives across regions and sectors to expand the impact of projects that would otherwise be too limited in scale to a have a substantive impact” (Fowler 2016, p. 184). Local governments surveyed for this study reported intergovernmental partners included environmental protection, transportation, and health agencies at local, state, and federal levels.

Additionally, both nonprofit and private organizations also engage in cooperative ties for air quality. These crosssectoral partnerships expand local air quality initiatives to include primary producers of emissions and community advocates. For nonprofits, these roles include advocacy or outreach campaigns and consulting with businesses or public sector agencies. On the other hand, private organizations, as primary producers of air pollution, work with public and nonprofit organizations locally to reduce their emissions (NAC 2017; NALGEP 2017). However, these partnerships also have potential for conflicting missions, as environmental policy can be highly contentious (Vig and Kraft 2016). Reported nonprofit partners included environmental protection, health, and sustainability focused advocacy groups, while reported private partners included local business, utilities, and trade associations.

\section{Methods}

\section{Data}

We collected data via survey of local government members of the National Association of Clean Air Agencies (NACAA), which is the common listing of local air agencies used in previous scholarship (Woods and Potoski 2010; Fowler 2016, 2018). We contacted the 118 local-level members of NACAA's online membership directory three times via mail and email (NACAA 2017). Of 81 total respondents (68.6\% of total sample), $72(61.0 \%)$ completed enough of the survey to be usable here, with 26 (32.1\% of respondents) responding via mail and 55 (67.9\%) digitally. Surveys were identical in question wording and fixed order, and exploratory data analyses indicate no differences between mail and digital responses. Additionally, respondents are both diverse and representative of NACAA membership regionally and institutionally. We found no systematic differences between survey respondent characteristics and average characteristics of all agencies or between respondents and non-respondents, suggesting the data sample is representative of local air agencies. However, local air agencies do not exist in 24 states as a result of both state- and local-level socio-political, economic, and environmental factors (Woods and Potoski 2010; Fowler 2018), which may create systematic differences between states with and without local air agencies. As such, this may create limitations in generalizing to local agencies with different missions; although, we do not believe our data is biased in generalizations to local air agencies specifically. 
This is an author-produced, peer-reviewed version of this article. The final, definitive version of this document can be found online at Journal for Critical Education Policy Studies, published by the Institute for Education Policy Studies. Copyright restrictions may apply.

We formulated survey questions to identify differences in cooperative or partnership relationships with broad categories of organizations that interact with local air agencies. Our two primary interests along these lines were which types of organizations local air agencies choose to work with and which types of organizations local air agencies avoid. To this end, we designed survey questions using Likert-scale responses to create a point of comparison between agencies along those two dimensions. However, we purposely avoided asking questions that project an ideal type of partnership functions in order to allow flexibility from respondents in evaluating their relationships with other organizations. Consequently, we did not ask questions about specific types or structures of activities. Although relying on respondent perceptions creates a limitation to our analysis, it also allows respondents to take into consideration the circumstances of their inter-organizational relationships when responding, which we believe captures a broader cross-section of cooperative behaviors.

\section{Dependent Variables}

We modeled dependent variables as ordinal dummy variables of local air agency managerial perceptions of partnerships with other types of organizations. We measured partnership with two constructs (partnership vs. nonpartnership) for five types of partners (other local, state, federal, nonprofit, and private). Partnership measures active cooperation with another organization of a specific type, while non-partnership measures not engaging with all potential partners available within a category. This allows for separate analyses of two interrelated constructs: 1) partnership formation based on actively engaging another organization of a particular type; and 2) either actively or passively not engaging broad categories of potential partners. While interrelated as part of the same process, partnership and non-partnership are distinct constructs, and not simply inverses. Partnership accounts for potential benefits offered by a specific organization, while non-partnership accounts for broad risks associated with organizations of a certain type. This distinction is important in delineating factors that motivate partnership versus factors that create obstacles to partnership by leading to non-partnership (i.e., what factors contribute to one versus factors that contribute to the other).

While improving air quality is the focus of most partnerships, they may form for different political and/or administrative reasons. Additionally, partnerships may take on different forms, as collaborative arrangements are not interchangeable when working with a diverse set of partners with different jurisdictions, authorities, and missions. For instance, contracting may be more likely with private organizations, while inter-local agreements for service provision may be more likely with other local agencies. If we assume these partnerships serve similar purposes though, we can also assume the same predictors influence them. That is, when considering forming a partnership, managers likely consider both forms needed and forms available.

Survey respondents rated constructs for each type of partner in their perceived area on a Likert scale from strongly disagree (one) to strongly agree (five). Table 2 summarizes measurement of partnership constructs and types of partners. For partnership, respondents rated state and local agencies highest with $92 \%$ and $90 \%$, and nonprofit and private organizations lowest with $63 \%$ and $43 \%$, respectively, responding strongly or somewhat agree. Conversely, for non-partnership, respondents rated nonprofit and private organizations highest with $19 \%$ and $13 \%$, and state and local agencies lowest with $11 \%$ and $11 \%$, respectively. While respondents favored partnership over non-partnership, that skew is more prominent for intergovernmental compared to cross-sectoral partnerships. Additionally, bi-variate correlation analysis indicates that inter-construct relationships are negative across all partner types, and intra-construct relationships are positive across all partner types. ${ }^{1}$ This suggests that partnering is distinct from non-partnering and both are distinct across intergovernmental and cross-sectoral dimensions, which supports separating partnership and non-partnership into two constructs. For ordinal probit models, we reorganized intergovernmental partners into three variables to better align with the comparative framework presented above: 1) combined intergovernmental (average of local, state, federal); 2) vertical intergovernmental (average of state and federal); and 3) horizontal intergovernmental (local). Appendix A summarizes descriptive statistics for variables.

\section{[Table 2 about here]}

\section{Predictor Variables}

We used six predictor variables to account for differences in benefits and risks related to each type of partner, and control for agency type. ${ }^{2}$ First, we use problem severity, local autonomy, and local competition as predictors of intergovernmental partnerships. Since effectiveness of a single agency's efforts in a collective action scenario are difficult to determine, we measure problem severity instead as annual median air quality index (AQI). AQI creates a 
This is an author-produced, peer-reviewed version of this article. The final, definitive version of this document can be found online at Journal for Critical Education Policy Studies, published by the Institute for Education Policy Studies. Copyright restrictions may apply.

standardized measure of air quality on a scale from 0 to 500, across six regulated criteria pollutants and AQCRs (EPA 2018b). Existing air quality conditions serve as the best measure of severity of policy problems faced by air agencies. If air quality is not a severe problem (i.e., low AQI), then agencies likely find little utility in partnering with other public-agencies. However, if air quality is a severe problem, then local agencies should be motivated to partner with other public agencies in order to better manage a problem across a regional area and reduce local problem severity. Intergovernmental partnership should increase and non-partnership decrease as AQI increases (i.e., problem severity increases).

Pre-existing state-local relations create a context for local risks at conscription by higher-level vertical partners. While there are several methods to capture differences in state-local relations, the Dillon's Rule versus Home Rule comparison is one of the most parsimonious. In Dillon's Rule states, local governments have narrow autonomy to partake only in activities authorized by states. On the other hand, in Home Rule states, local governments have broad autonomy and delegated powers from states (Krane, Rigos, and Hill 2001; NLC 2017). If local governments have broad autonomy, then forming partnerships with vertical partners creates a risk of lost autonomy. However, if local governments have narrow autonomy, then there is little risk in vertical partnerships, as they essentially have nothing to lose. We measure risks to local autonomy as Dillon's Rule versus Home Rule. Currently, 31 states apply Dillon's Rule; 10 states, Home Rule; and, 9 states, a modified version of Dillon's Rule (NLC 2017). We created an ordinal dummy variable with categories ordered as: Dillon's Rule (0), limited or modified Dillon's Rule (1), and Home Rule (2). Vertical intergovernmental partnership should increase and non-partnership decrease as local government autonomy decreases (i.e., Dillon's Rule).

Previous findings on inter-local competition indicate that larger cities act more independently in policy innovation, due to decrease competitive pressure. Additionally, smaller cities have less capacity and resources to compete with larger cities in their area (Walker 2006; Shipan and Volden 2005, 2008; Fowler 2016). Thus, comparative jurisdiction size reflects perceived threats of competition from horizontal partners. If local governments are relatively small, then they are likely less willing to risk investing in a cooperative relationship that may revert to competition. However, if local governments are relatively large, then forming horizontal partnerships is a low risk proposal. We measure risks of local competition as portion of metropolitan area population under agency jurisdiction (Shipan and Volden 2005; Fowler 2018). Horizontal partnership should increase and non-partnership decrease as risk of competition decreases (i.e., agency jurisdiction increases).

Second, we use local socio-economic equity and available resources as predicators of cross-sectoral partnerships. Previous research indicates environmental justice is a pervasive issue in urban areas, with traditionally disenfranchised groups, such as low-income individuals, having a higher probability of exposure to pollutants (Harper, et al. 2013). While issues of environmental inequality are widespread and well-documented, there are few generalizable measures available at the local-level. Nevertheless, some scholarship indicates local economic inequality is a surrogate for potential environmental inequity (Harper, et al. 2013). Additionally, areas with high economic inequality are more likely to have capacity for public-nonprofit partnerships, with more non-profits and an institutional culture supporting these arrangements (Gronbjerg and Paarlberg 2001). If local areas have high economic inequality, then forming partnerships with non-profit organizations creates significant potential benefits by offering expanded services to under-privileged populations. However, if areas have low economic inequality, then there is little potential benefit in forming public-nonprofit partnerships. We measure local socio-economic equity as ratio of median household income in the $20^{\text {th }}$ percentile to the $80^{\text {th }}$ percentile for each MSA or $\mu$ SA. Public-nonprofit partnership should increase and non-partnership decrease as inequity increases (i.e., inequity ratios increase).

Since efficiency is a rate of both resources expended and change in outcomes over time, a cross-sectional research design cannot effectively capture efficiency in the most conventional sense. However, in a more practical way, available financial resources compared to problem severity can also serve as a measure of resource pressure, where we consider expenditure availability and problem severity together. While this approach creates both theoretical and methodological limitations, it does provide meaningful measurement of resource pressures, and is testable with available data. As such, if available resources are high and air quality is not a problem, then there is little to gain from public-private partnerships. However, if available resources are low in comparison to problem severity, then local agencies would be motivated to partner with private organizations in order to gain access to extra-governmental resources or improve their use of resources related to problem severity. 
This is an author-produced, peer-reviewed version of this article. The final, definitive version of this document can be found online at Journal for Critical Education Policy Studies, published by the Institute for Education Policy Studies. Copyright restrictions may apply.

We measured available resources as per capita spending rate per AQI point, capturing both ratio of spending inputs to problem severity and comparative resources between agencies. However, as a higher AQI means higher problem severity (i.e., more pollutants), AQI is inverted by subtracting it from 100 (maximum allowable for NAAQS attainment) before dividing it by per capita spending rate. ${ }^{3}$ This creates a comparable measure that reflects amount of spending per iteration of problem severity. While we collected spending data via survey, self-reported budget data may suffer from errors. As budgets of local government in the data sample are not all organized around specific programs, this serves as the best approximation available though. Public-private partnership should increase and nonpartnership decrease as available resources decrease (i.e., spending per air improvement iteration increases).

Finally, we control for agency types with a dummy variable comparing regional agencies to city and/or county agencies (base category). These represent distinct types of government agencies with different ties to other public agencies, authorities, and jurisdictions. Additionally, previous research indicates a different set of pressures affect regional planning agencies when joining networks compared to municipalities (Fowler 2018). With more institutional autonomy and capacity, regional planning agencies should be less likely to partner and more likely to non-partner, compared to city and county agencies. Given the numerous variables, we summarize expected directional relationships for predictors of partnership and non-partnership in table 3.

\section{[Table 3 about here]}

\section{$\underline{\text { Analysis }}$}

We use ordinal probit models to assess predictors of partnership and non-partnership, with coefficients reported. Additionally, we corrected for heteroscedasticity with robust standard errors (Bartlett, Kotrlik, and Higgins 2001; Mendard 2002; Shelley 2008). Further diagnostics indicate no other issues. Although the full dataset includes 72 observations, ordinal probit models include 63 or 64 observations due to missing data. To address causation issues and account for lag in partnership formation, predictor variables are observed for 2013 and dependent variables measured by survey in $2016 .{ }^{4}$

\section{Results}

Table 4 presents results of ordinal probit models for partnership, and table 5, for non-partnership. Additionally, given the numerous findings presented, table 6 summarizes the statistically significant results. First, problem severity is the primary driver of partnership across all types of partners. As air quality worsens, partnership with every type of organization increases. These findings are consistent with predictions concerning intergovernmental partnership formation. While findings for local competition and autonomy support predictions for combined intergovernmental, they are not consistent with predictions for vertical and horizontal intergovernmental specifically. Additionally, other variables had significant relationships that we did not predict. Most importantly, available resources is a significant predictor of combined, vertical, and horizontal intergovernmental, where increased available resources leads to decreased partnership. For cross-sectoral partners, problem severity is the only significant predictor of publicnonprofit and public-private partnership, and income inequality and available resources do not have significant relationships.

\section{[Tables 4, 5, \& 6 about here]}

Second, drivers of non-partnership are much more diverse across types of organizations than for partnership. Interestingly, available resources appears to be a key source of non-partnership, as it demonstrates a significant, consistent relationship with all types of partners. Findings for vertical and horizontal intergovernmental are consistent with expectations, as increased autonomy and decreased competition lead to increased non-partnership, respectively. Additionally, local competition also proved to be a significant predictor of combined and vertical intergovernmental, where increased competition leads to decreased non-partnership. For cross-sectoral partners, findings are consistent with predictions, as decreases in income inequality and increases in available resources lead to increased nonpartnership with non-profit and private, respectively. Finally, regional agencies are more likely to non-partner with private and non-profit organizations than municipal governments, which is likely a result of their larger authority and jurisdictions. However, certain findings for both partnership and non-partnership were only significant below 0.1 probability level, so these findings may be less reliable than others presented here. Additionally, while public- 
This is an author-produced, peer-reviewed version of this article. The final, definitive version of this document can be found online at Journal for Critical Education Policy Studies, published by the Institute for Education Policy Studies. Copyright restrictions may apply.

nonprofit and public-private were statistically significant below 0.05 probably level, combined, vertical, and horizontal intergovernmental models were also only significant below 0.1 probability level. McFadden's Pseudo- $\mathrm{R}^{2}$ statistics indicate models are moderately strong predictors of both partnership and non-partnership.

\section{$\underline{\text { Limitations }}$}

A few notable limitations to these findings warrant discussion. First, data and findings are likely only generalizable to a specific group of agencies. Air quality is a unique policy area that addresses a complex problem and relies on "top-down" elements institutionalized by the CAA, making it significantly different from some other public goods and services. As such, air quality is reliant much more on intergovernmental partnerships than cross-sectoral partnerships, which decreases likelihood of public-private or public-nonprofit partnerships. Second, while predictor variables correlate to at least one dependent variable and vice versa, these measures do not take into account how specific agencies may measure concepts like available resource, or how they perceive risks of competition or to their autonomy. Furthermore, analyses do not isolate effects of specific forms of partnership (e.g., contracting), which limits insights into how different forms develop. As policy characteristics, performance metrics, and partnership forms can affect cooperation, these findings may not be wholly applicable to other policy areas that vary in complexity, rely on different cooperative strategies, include less rigid governing legislation, or involve more cross-sectoral than intergovernmental partnerships.

Third, both partnership and non-partnership require at least some amount of interpretation from respondents, which creates possibilities that respondents may interpret the same item differently. There were several assumptions made in designing survey items that led to leaving items ambiguous though: partnership intensity varies between organizational categories, forms, and agency cultures (i.e., weak partnerships for some may be substantive to others); collaborative arrangements are not interchangeable when working with a diverse set of partners (i.e., contracting is more likely for public-private partnerships, while service agreements more likely for inter-local partnerships); and, partner availability fluctuates across geographic areas (i.e., organizations working on air quality in one AQCR may not be doing so in other AQCRs). However, there is also an assumption that as members of a national association of similar agencies (i.e., NACAA), respondents have knowledge of partnership norms in air quality, and considered those when responding. That is, respondents have some objective bar at which to measure themselves that takes into account complex contextual issues and creates a point of comparison across many agencies situated in different circumstances. While relying on measures that are more concrete may create more face validity, it would assume that all local air agencies have similar partnership options in practice. On the other hand, by relying on perceptions, analyses examine perceived partnership and non-partnership, with individual interpretations potentially creating bias.

Fourth, theoretically, partnership and non-partnership are two separate stages of a multi-stage process that ranges from a default position without partners to an actively chosen position of partnership. However, in practice, these stages likely occur concurrently, which makes it difficult to separate concepts in partnership formation processes. Methodologically, partnering and non-partnering are tested separately, but models do not account for how these constructs link together in a process. As such, findings provide some insight into which factors contribute to partnership and which to non-partnership, but are limited in identifying how partnership and non-partnership relate to each other or how factors may simultaneously influence both. Finally, while survey data is representative of air agencies and findings are statistically significant, small n-sizes leaves our analyses with limited statistical power.

\section{Conclusions}

Our findings suggest four notable conclusions. First, as cooperation with every potential partner with shared policy goals is impractical, non-partnership is an important tool for not over-extending cooperative capacity (McGuire and Agranoff 2011; Provan and Lemaire 2012). For local air agencies, there are factors correlated with both partnership and non-partnership. However, previous scholarship almost exclusively focuses on the former, and makes little or no investigation of the latter. The calculus of partnership formation is more complex than this though, where partnerships are a function of both potential benefits and risks. As such, understanding non-partnership may provide insights into scenarios where partnerships do not form between mismatched organizations even when need and opportunity exist. For managers, these findings suggest that non-partnership is another managerial tool for steering public-sector agencies towards their goals, where avoiding poorly suited partners may be as important as attracting well-matched partners. 
This is an author-produced, peer-reviewed version of this article. The final, definitive version of this document can be found online at Journal for Critical Education Policy Studies, published by the Institute for Education Policy Studies. Copyright restrictions may apply.

Second, two different sets of factors drive partnership and non-partnership, which include both shared goals and risks associated with specific types of organizations, respectively. Findings for partnership largely correspond with existing arguments that partnerships form around shared problems or goals. More specifically, problem severity is a chief motivator regardless of partner type, suggesting need to improve policy outcomes is a major driver of partnerships. This is particularly notable for ties to private and nonprofit organizations, where air quality is the only significant predictor of partnership. Nevertheless, other factors (i.e., available resources) affect intergovernmental partnership, which is consistent with scholarship on improving efficiency through economies of scale (Andrews and Entwistle 2010). However, findings on non-partnership suggests that advantages and disadvantages offered by different types of organizations are a primary obstacle to partnerships. In some cases, these factors may result in organizations not actively pursuing partnerships, and in other cases, they may present an obstacle to pursuing partnerships. More specifically, non-partnership is affected by: problem severity with combined intergovernmental partners; local autonomy with vertical partners; local competition with horizontal partners; income inequality with nonprofit partners; and available resources with private partners. Additionally, available resources appears to affect more than one type of partner. Thus, there are both motivators and obstacles for partnership, with motivators tied to problem severity and obstacles to other competing interests.

Third, from a practical perspective, managers trying to form partnerships have to address two sets of concerns when "selling" themselves as partners: 1) how will partnership improve policy outcomes; and 2) how big of a threat is an organization as a partner. Despite an emphasis on cooperation and partnership in recent decades, partnerships can potentially hinder organizational performance, especially if partners are ill-suited for the situation (Longoria 2005; Hodge and Greve 2007). As such, managers must understand how partnership creates new opportunities or capacities for managing a complex problem. If new capacities do not complement existing capacities, then it is likely that partnership will create additional costs in organizing efforts without corresponding improvements in policy outcomes. Furthermore, managers must also understand risks involved when partnering with other organizations. Investing time and resources as well as constructing strategies relying on efforts from others creates an immense amount of risks for public managers. Consequently, when risks outweigh benefits, non-partnership is likely a better choice than partnership. However, by considering these issues early, managers can be better prepared for identifying benefits and risks of potential partnerships, as well as communicating those benefits and risks to their partners in order to encourage deeper consideration of these issues on all sides.

Fourth, different types of organizations offer different advantages and disadvantages for partnership (or nonpartnership). Findings suggest that all types of organizations offer an advantage for addressing problem severity. However, there are specific organizations that are perceived as offering more advantages (or at least, less disadvantages), related to issues such as available resources, income inequality, competition, or autonomy. While previous scholarship examines some of these dimensions, there are few examples of an integrated framework for comparing organizational types for purposes of partnership. As such, these findings provide additional insight into how organizations compare to each other. In practice, these findings suggest that managers should consider multiple organizational dimensions when analyzing potential partnerships, with advantages and disadvantages varying significantly across intergovernmental and cross-sectoral levels.

Additional research should be undertaken to determine more specifically mechanisms by which partnership formation occurs (or not) for public-sector organizations. Most importantly, there should be further examination of the multistage process that leads to partnership to provide further insights into which factors affect choices at different decisionpoints, and how separate stages are interrelated, overlapping, and/or intersecting. Additionally, as findings did not strictly conform to expected theoretical relationships, future research is necessary to develop alternative frameworks for comparison or apply the framework to other policy areas that may include operational differences that better align with its theoretical underpinnings (Lundin 2007; Andrews and Entwistle 2010). Methodologically, future research should employ other research designs, including qualitative approaches and large n-size quantitative studies, to garner robust findings about these relationships. Understanding why non-partnerships persist is a key to further insights into partnership formation and building effective collaborations with public-sector organizations and networks for public service delivery. 
This is an author-produced, peer-reviewed version of this article. The final, definitive version of this document can be found online at Journal for Critical Education Policy Studies, published by the Institute for Education Policy Studies. Copyright restrictions may apply.

\section{Notes}

1. Inter-construct relationships range from -.493 for federal to -.256 for local, while intra-construct relationships range from .699 for state-federal non-partnership and .174 for local-nonprofit nonpartnership

2. Correlations of predictor variables range from .472 to -.337. VIF statistics indicate no multicollinearity exists in any models presented.

3. We tested alternative versions of this variable, with results similar to those reported here. However, statistical tests indicated the version used was the best fit for the data.

4. While the largest single annual increase in federal spending on pollution control and abatement since 1977 occurred in 2010, spending returned to previous levels starting in 2013, which marked a contraction in available resources for air quality programs that had expanded in the interim (Office of Management and Budget 2017). If partnerships were partially motivated by resource-seeking, then air quality agencies would be likely to adapt behaviors starting in 2013 in response to changes at the federal-level. Additionally, we assume partnership formation is a multi-stage process that occurs over multiple years. We tested lag variations with diagnostics indicating a three-year lag was the best fit for the data. As such, we use 2013 observations to measure conditions that likely affect the partnership formation process that unfolds over approximately three years and would yield stable partnerships by 2016 .

\section{Author Biography}

Luke Fowler is an assistant professor and Director of the Masters of Public Administration program in the School of Public Service at Boise State University. His research interests include environmental and energy policy, state and local government, and administrative and policy theory. His work has appeared in State \& Local Government Review, American Review of Public Administration, Environmental Politics, and Review of Policy Research.

\section{References}

Acar, M., C. Guo, and K. Yang. 2008. Accountability When Hierarchical Authority is Absent. American Review of Public Administration 38(1): 3-23. Accessed on September 24, 2018. Available online at http://journals.sagepub.com/doi/abs/10.1177/0275074007299481

Agranoff, R. and M. McGuire. 1999. Expanding Intergovernmental Management's Hidden Dimensions. American Review of Public Administration 29(4): 352-369. Accessed on September 24, 2018. Available online at http://journals.sagepub.com/doi/abs/10.1177/02750749922064472

Agranoff, R. and M. McGuire. 2001. Big Questions in Public Network Management Research. Journal of Public Administration Research \& Theory 11(3): 295-326. Accessed on September 24, 2018. Available online at https://academic.oup.com/jpart/article/11/3/295/982742

Alexander, J. and R. Nank. 2009. Public-Nonprofit Partnership: Realizing the New Public Service. Administration \& Society 41(3): 364-386. Accessed on September 24, 2018. Available online at http://journals.sagepub.com/doi/abs/10.1177/0095399709332296

Andrews, R. and T. Entwistle. 2010. Does Cross-Sectoral Partnership Deliver? An Empirical Exploration of Public Service Effectiveness, Efficiency, and Equity. Journal of Public Administration Research \& Theory 20(3): 679-701. Accessed on September 24, 2018. Available online at https://academic.oup.com/jpart/article/20/3/679/951180

Axelrod, R. 2006. The Evolution of Cooperation, revised ed. New York: Basic Books.

Bartlett, J.E., J.W. Kotrlik, and C.C. Higgins. 2001. Organizational Research: Determining Appropriate Sample Size in Survey Research. Information Technology, Learning, and Performance Journal 19(1): 43-50. Accessed on September 24, 2018. Available online at ftp://149.222-6269.ftth.swbr.surewest.net/TreePDF/Determing\%20Appropriate\%20Sample\%20Size\%20in\%20Survey\%20 Research.pdf

Bedard, K. and H.E. Frech. 2009. Prison Health Care: Is Contracting Out Healthy? Health Economics 18(11): 12482160. Accessed on September 24, 2018. Available online at https://onlinelibrary.wiley.com/doi/abs/10.1002/hec.1427

Belden, R.S. 2001. The Clean Air Act. Chicago: American Bar Association, Section of Environment, Energy, and Resources. 
This is an author-produced, peer-reviewed version of this article. The final, definitive version of this document can be found online at Journal for Critical Education Policy Studies, published by the Institute for Education Policy Studies. Copyright restrictions may apply.

Bennett, L.L. and C.W. Howe. 1998. The Interstate River Compact: Incentives for Noncompliance. Water Resources Research 34(3): 485-495. Accessed on September 24, 2018. Available online at https://agupubs.onlinelibrary.wiley.com/doi/abs/10.1029/97WR03384

Chen, Y.C. and K. Thurmaier. 2009. Interlocal Agreements as Collaborations: An Empirical Investigation of Impetuses, Norms, and Success. American Review of Public Administration 39(5): 536-552. Accessed on September 24, 2018. Available online at http://journals.sagepub.com/doi/abs/10.1177/0275074008324566

Cohen, S. and W. Eimicke. 2008. The Responsible Contract Manager: Protecting the Public Interest in an Outsourced World. Washington, DC: Georgetown University Press.

Feiock, R.C. and J.T. Scholtz. 2009. Self-Organizing Governance of Institutional Collective Action Dilemmas: An Overview. In Self-Organizing Federalism: Collective Mechanisms to Mitigate Institutional Collective Action Dilemmas edited by R.C. Feiock and J.T. Scholtz (pgs. 3-32). New York: Cambridge University Press.

Feiock, R.C., A. Steinacker, and H.J. Park. 2009. Institutional Collective Action and Economic Development Joint Ventures. Public Administration Review 69(2): 256-270. Available online at https://onlinelibrary.wiley.com/doi/abs/10.1111/j.1540-6210.2008.01972.x

Fischer, M., Ingold, K., Sciarini, P., and Varone, F. 2012. Impacts of Market Liberalization on Regulatory Network: A Longitudinal Analysis of the Swiss Telecommunications Sector. Policy Studies Journal 40(3): 435-457. Accessed on September 24, 2018. Available online at https://onlinelibrary.wiley.com/doi/abs/10.1111/j.1541-0072.2012.00460.x

Fowler, L. 2016. Local Governments: The 'Hidden Partners’ of Air Quality Management. State \& Local Government Review 48(3): 175-88. Accessed on September 24, 2018. Available online at http://journals.sagepub.com/doi/abs/10.1177/0160323X16656918

Fowler, L. 2018. When Need Meets Opportunity: Expanding Local Air Networks. American Review of Public Administration 48(3): 219-31. Accessed on September 24, 2018. Available online at http://journals.sagepub.com/doi/abs/10.1177/0275074016680026

Gazley, B. and J.L. Brudney. 2007. The Purpose (and Perils) of Government-Nonprofit Partnership. Nonprofit and Voluntary Sector Quarterly 36(3): 389-415. Accessed on September 24, 2018. Available online at http://journals.sagepub.com/doi/abs/10.1177/0899764006295997

Gordon, V. 2007. Partners or Competitors? Perceptions of Regional Economic Development Cooperation in Illinois. Economic Development Quarterly 21(1): 60-78. Accessed on September 24, 2018. Available online at http://journals.sagepub.com/doi/abs/10.1177/0891242406291573

Graddy, E.A. and Chen, B. 2006. Influences on the Size and Scope of Networks for Social Service Delivery. Journal of Public Administration Research \& Theory 16(4): 533-552. Accessed on September 24, 2018. Available online at https://academic.oup.com/jpart/article/16/4/533/921601

Gronbjerg, K.A. and L. Paarlberg. 2001. Community Variations in the Size and Scope of the Nonprofit Sector: Theory and Preliminary Findings. Nonprofit and Voluntary Sector Quarterly 30(4): 684-706. Accessed on September 24, 2018. Available online at http://journals.sagepub.com/doi/abs/10.1177/0899764001304004

Harper, S., E. Ruder, H.A. Roman, A. Geggel, O. Nweke, D. Payne-Sturges, and J.I. Levy. 2013. Using Inequality Measures to Incorporate Environmental Justice into Regulatory Analyses. International Journal of Environmental Research and Public Health 10(9): 4039-4059. Accessed on September 24, 2018. Available online at https://www.mdpi.com/1660-4601/10/9/4039

Hill, M. and P. Hupe. 2014. Implementing Public Policy, $3^{\text {rd }}$ ed. Thousand Oaks, CA: Sage.

Hodge, G.A. and C. Greve. 2007. Public-Private Partnerships: An International Performance Review. Public Administration Review 67(3): 545-558. Accessed on September 24, 2018. Available online at https://onlinelibrary.wiley.com/doi/abs/10.1111/j.1540-6210.2007.00736.x

Isett, K.R., I.A. Mergel, K. LeRoux, P.A. Mischen, and R.K. Rethemeyer. 2011. Networks in Public Administration Scholarship: Understanding Where We Are and Where We Need to Go. Journal of Public Administration Research \& Theory 21(1): 157-173. Accessed on September 24, 2018. Available online at https://academic.oup.com/jpart/article/21/suppl_1/i157/912024

Johnson, W.C. 2014. Public Administration: Partnerships in Public Service, $5^{\text {th }}$ ed. Long Grove, IL: Waveland Press.

Keast, R., M.P. Mandell, K. Brown, and G. Woolcock. 2004. Network Structures: Working Differently and Changing Expectations. Public Administration Review 64(3): 363-371. Accessed on September 24, 2018. Available online at https://onlinelibrary.wiley.com/doi/abs/10.1111/j.1540-6210.2004.00380.x 
This is an author-produced, peer-reviewed version of this article. The final, definitive version of this document can be found online at Journal for Critical Education Policy Studies, published by the Institute for Education Policy Studies. Copyright restrictions may apply.

Kettl, D.F. 2006. Managing Boundaries in American Administration: The Collaboration Imperative. Public Administration Review 66(s1): 10-19. Available online at https://onlinelibrary.wiley.com/doi/abs/10.1111/j.1540-6210.2006.00662.x

Koliba, C.J., R.M. Mills, and A. Zia. 2011. Accountability in Governance Networks: An Assessment of Public, Private, and Nonprofit Emergency Management Practices Following Hurricane Katrina. Public Administration Review 71(2): 210-220. Accessed on September 24, 2018. Available online at https://onlinelibrary.wiley.com/doi/abs/10.1111/j.1540-6210.2011.02332.x

Krane, D., N. Rigos, and M. Hill. 2001. Home Rule in America. Washington, D.C.: CQ Press.

Kwon, S.W. and R.C. Feiock. 2010. Overcoming the Barriers to Cooperation: Intergovernmental Service Agreements. Pubic Administration Review 70(6): 876-884. Available online at https://onlinelibrary.wiley.com/doi/abs/10.1111/j.1540-6210.2010.02219.x

Lee, Y., Lee, I.W., and Feiock, R.C. 2012. Interorganizational Collaboration Networks in Economic Development Policy: An Exponential Random Graph Model Analysis. Policy Studies Journal 40(3): 547-573. Accessed on September 24, 2018. Available online at https://onlinelibrary.wiley.com/doi/abs/10.1111/j.15410072.2012.00464.x

Lester, J.P. and E.N. Lombard. 1998. Environmental Regulation and State-Local Relations. In Governing Partners, edited by R.L. Hansen, 139-160. Boulder, CO: Westview Press.

Ling, T. 2002. Delivering Joined-up Government in the UK: Dimensions, Issues, and Problems. Public Administration 80(4): 615-642. Accessed on September 24, 2018. Available online at https://onlinelibrary.wiley.com/doi/abs/10.1111/1467-9299.00321

Lundin, M. 2007. When Does Cooperation Improve Public Policy Implementation? Policy Studies Journal 35(4): 629-652. Accessed on September 24, 2018. Available online at https://onlinelibrary.wiley.com/doi/abs/10.1111/j.1541-0072.2007.00240.x

McGuire, M. and R. Agranoff. 2011. The Limitations of Public Management Networks. Public Administration. 89(2): 265-284. Accessed on September 24, 2018. Available online at https://onlinelibrary.wiley.com/doi/abs/10.1111/j.1467-9299.2011.01917.x

McGuire, M. and C. Silvia. 2010. Effect of Problem Severity, Managerial and Organizational Capacity, and Agency Structure on Intergovernmental Collaboration: Evidence from Local Emergency Management. Public Administration Review 70(2): 279-288. Accessed on September 24, 2018. Available online at https://onlinelibrary.wiley.com/doi/abs/10.1111/j.1540-6210.2010.02134.x

McQuaid, R.W. 2010. Theory of Organizational Partnerships: Partnership Advantages, Dis-advantages and Success Factors. In The New Public Governance? edited by S.P. Osborne, 127-148. New York: Routledge.

Minkler, M., V.B. Vasquez, M. Tajik, and D. Petersen. 2008. Promoting Environmental Justice through Community-based Participatory Research: The Role of Community and Partnership Capacity. Health Education \& Behavior 35(1): 119-137. Accessed on September 24, 2018. Available online at http://journals.sagepub.com/doi/abs/10.1177/1090198106287692

Morris, J.C. and K. Miller-Stevens. 2015. Advancing Collaboration Theory: Models, Typologies, and Evidence. New York: Routledge.

National Association of Clean Air Agencies (NACAA). 2017. Find a State or Local Agency. http://www.4cleanair.org/agencies [Retrieved February 1, 2017].

National Association of Local Government Environmental Professionals (NALGEP). 2017. Profiles of Local Clean Air Innovation. http://www.nalgep.org/uploads/pdf/publi14.pdf [Retrieved February 1, 2017].

National Association of Counties (NAC). 2017. Air Quality Improvement: Guide for Local Governments. http://www.naco.org/sites/default/files/documents/AQ_Factsheet\%20\%20Air\%20Quality\%20Improvement\%20Guide\%20for\%20Local\%20Governments.pdf [Retrieved February 1, 2017].

National League of Cities (NLC). 2017. Local Government Authority. http://www.nlc.org/build-skills-andnetworks/resources/cities-101/city-powers/local-government-authority [Retrieved February 1, 2017].

Office of Management and Budget. 2017. Budget: Historical Tables. The White House. https://www.whitehouse.gov/omb/budget/Historicals [Retrieved October 1, 2017].

Osborne, D. and T. Gaebler. 1992. Reinventing Government. New York: Plume.

Ostrom, E. 2015. Governing the Commons: The Evolution of Institutions for Collective Action. Cambridge, UK: Cambridge University Press.

O’Toole, L.J. 2015. Networks and Networking: The Public Administrative Agendas. Public Administration Review 75(3): 361-371. Accessed on September 24, 2018. Available online at https://onlinelibrary.wiley.com/doi/abs/10.1111/puar.12281 
This is an author-produced, peer-reviewed version of this article. The final, definitive version of this document can be found online at Journal for Critical Education Policy Studies, published by the Institute for Education Policy Studies. Copyright restrictions may apply.

Park, H. and Rethemeyer, R. 2014. The Politics of Connections: Assessing the Determinants of Social Structure in Policy Networks. Journal of Public Administration Research \& Theory 24(2): 349-379. Accessed on September 24, 2018. Available online at https://academic.oup.com/jpart/article/24/2/349/915143

Provan, K.G. and Huang, K. 2012. Resource Tangibility and the Evolution of a Publicly Funded Health and Human Services Network. Public Administration Review 72(3): 366-375. Available online at https://onlinelibrary.wiley.com/doi/abs/10.1111/j.1540-6210.2011.02504.x

Provan, K.G. and R.H. Lemaire. 2012. Core Concepts and Key Ideas for Understanding Public Sector Organizational Networks: Using Research to Inform Scholarship and Practice. Public Administration Review 72(5): 638-648. Accessed on September 24, 2018. Available online at https://onlinelibrary.wiley.com/doi/abs/10.1111/j.1540-6210.2012.02595.x

Provan, K.G. and H.B. Milward. 2001. Do Networks Really Work? A Framework for Evaluating Public-Sector Organizational Networks. Public Administration Review 61(4): 414-423. Accessed on September 24, 2018. Available online at https://journals.aom.org/doi/abs/10.5465/apbpp.1999.27628083

Raab, J. and H.B. Milward. 2003. Dark Networks as Problems. Journal of Public Administration Research \& Theory 13(4): 413-439. Accessed on September 24, 2018. Available online at https://academic.oup.com/jpart/article/13/4/413/922418

Scicchitano, M.J. and D.M. Hedge. 1993. From Coercion to Partnership in Federal Partial Preemption: SMCRA, RCRA, and OSH Act. Publius 23(4): 107-121. Accessed on September 24, 2018. Available online at https://academic.oup.com/publius/article-abstract/23/4/107/1839980

Shelley, M.C. 2008. Multivariate Techniques for Dichotomous Dependent Variables: An Application to Public Policy. In Handbook of Research Methods in Public Administration, $2^{\text {nd }}$ ed. edited by K. Yang and G.J. Miller, 489-513. Boca Raton, FL: Taylor and Francis Group.

Shipan, C. and C.M. Volden. 2005. Diffusion, Preemption, and Venue Shopping: The Spread of Local Antismoking Policies. Scholars in Health Policy Research Program Working Papers Series-31. Robert Wood Johnson Foundation.

Shipan, C. and C.M. Volden. 2008. The Mechanisms of Policy Diffusion. American Journal of Political Science 52(4): 840-857. Accessed on September 24, 2018. Available online at https://onlinelibrary.wiley.com/doi/abs/10.1111/j.1540-5907.2008.00346.x

Skelcher, C. 2005. Public-Private Partnerships and Hybridity. In The Oxford Handbook of Public Management edited by E. Ferlie, L.E. Lynn, and C. Pollitt, 347-370. Oxford, UK: Oxford University Press.

Smith, K.B. and C.W. Larimer. 2009. Public Policy Theory Primer. Boulder, CO: Westview.

Teisman, G.R. and E. Klijn. 2002. Partnership Arrangements: Governmental Rhetoric or Governance Scheme? Public Administration Review 62(2): 197-205. Available online at https://onlinelibrary.wiley.com/doi/abs/10.1111/0033-3352.00170

Thomson, A.M. and J.L. Perry. 2006. Collaboration Processes: Inside the Black Box. Public Administration Review 66(s): 20-32. Accessed on September 24, 2018. Available online at https://onlinelibrary.wiley.com/doi/abs/10.1111/j.1540-6210.2006.00663.x

Thurmaier, K. and C. Wood. 2002. Interlocal Agreements as Overlapping Social Networks: Picket Fence Regionalism in Metropolitan Kansas City. Public Administration Review 62(5): 585-598. Accessed on September 24, 2018. Available online at https://onlinelibrary.wiley.com/doi/abs/10.1111/1540-6210.00239

U.S. Bureau of Economic Analysis (BEA). 2018. Regional Data. http://www.bea.gov/iTable/iTable.cfm?reqid=70\&step=1\&isuri=1\&acrdn=3\#reqid=70\&step=1\&isuri=1 [Retrieved February 1, 2017].

U.S. Census Bureau. 2018. American Fact Finder: Download Center. https://factfinder.census. gov/faces/nav/jsf/pages/download_center.xhtml\# [Retrieved February 1, 2017].

U.S. Environmental Protection Agency (EPA). 2018a. Air Data. http://www3.epa.gov/airdata/ [Retrieved February 1, 2017].

U.S. Environmental Protection Agency (EPA). 2018b. Air Quality Index. http://airnow.gov/index.cfm?action=aqibasics.aqi [Retrieved February 1, 2017].

Vig, N.J., and M.E. Kraft. 2016. Environmental Policy: New Directions for the Twenty-First Century. Washington, DC: CQ Press.

Walker, R. M. 2006. Innovation Type and Diffusion: An Empirical Analysis of Local Government. Public Administration 84(2): 311-335. Accessed on September 24, 2018. Available online at https://onlinelibrary.wiley.com/doi/abs/10.1111/j.1467-9299.2006.00004.x 
This is an author-produced, peer-reviewed version of this article. The final, definitive version of this document can be found online at Journal for Critical Education Policy Studies, published by the Institute for Education Policy Studies. Copyright restrictions may apply.

Walker, R.M. and R. Andrews. 2015. Local Government Management and Performance: A Review of Evidence. Journal of Public Administration Research \& Theory 25(1): 101-133. Accessed on September 24, 2018. Available online at https://academic.oup.com/jpart/article/25/1/101/885328

Wallis, J. and B. Dollery. 2006. Revitalizing the Contribution Non-profit Organizations Can Make to the Provision of Human Services. International Journal of Social Economics 33(7): 491-511. Accessed on September 24, 2018. Available online at https://www.emeraldinsight.com/doi/full/10.1108/03068290610673261

Warner, M.E. and G. Bel. 2008. Competition or Monopoly? Comparing Privatization of Local Public Services in the U.S. and Spain. Public Administration 86(3): 723-736. Accessed on September 24, 2018. Available online at https://onlinelibrary.wiley.com/doi/abs/10.1111/j.1467-9299.2008.00700.x

Weisbrod, B.A. 1997. The Future of the Nonprofit Sector: Its Entwining with Private Enterprise and Government. Journal of Policy Analysis and Management 16(4): 541-555. Accessed on September 24, 2018. Available online at https://onlinelibrary.wiley.com/doi/abs/10.1002/(SICI)1520-6688(199723)16:4\%3C541::AIDPAM2\%3E3.0.CO;2-G

Woods, N.D., and M. Potoski. 2010. Environmental Federalism Revisited: Second-Order Devolution in Air Quality Regulation. Review of Policy Research 27(6): 721-739. Accessed on September 24, 2018. Available online at https://onlinelibrary.wiley.com/doi/abs/10.1111/j.1541-1338.2010.00468.x

Zimmerman, J.F. 2009. Contemporary American Federalism: The Growth of National Power. Albany, NY: State University of New York Press.

Tables

Table 1. Comparison of Types of Partners in a Multi-Dimensional Environment

\begin{tabular}{|c|c|c|c|}
\hline Type of Partnership & Operation Extension & Benefits & Risks \\
\hline Intergovernmental & & Effectiveness & Conscription \\
\hline -Vertical Intergovernmental & Comprehensive & & Competition \\
\hline -Horizon Intergovernmental & Comparative & & Principal-agent \\
\hline Cross-sectoral & & & \\
\hline -Public-Nonprofit & Market failures & Equity & \\
\hline -Public-Private & Market & Efficiency & \\
\hline
\end{tabular}

Table 2. Measurement of Partners Constructs and Types of Partners

\begin{tabular}{|l|l|l|}
\hline Constructs & Types of Partners & Responses \\
\hline $\begin{array}{l}\text { 1. Partnership: My office actively cooperates or } \\
\text { partners with [type of partner] working on air } \\
\text { quality issues in my area. }\end{array}$ & $\begin{array}{l}\text { 1. Other local agencies } \\
\text { 2. State agencies }\end{array}$ & 1. Strongly Disagree \\
2. Non-Partnership: There are [type of partner] & 3. Federal agencies & 3. Nomewhat Disagree \\
$\begin{array}{l}\text { working on air quality issues in my area that my } \\
\text { office does not cooperate or partner with. }\end{array}$ & 4. Nonprofit & 4. Somewhat Agree \\
& 5. Private organizations & 5. Somewhat Disagree \\
\hline
\end{tabular}


This is an author-produced, peer-reviewed version of this article. The final, definitive version of this document can be found online at Journal for Critical Education Policy Studies, published by the Institute for Education Policy Studies. Copyright restrictions may apply.

Table 3. Summary of Expected Directional Relationships

\begin{tabular}{|c|c|c|c|c|c|c|}
\hline & \begin{tabular}{|l|}
$\begin{array}{l}\text { Problem } \\
\text { severity }\end{array}$ \\
\end{tabular} & $\begin{array}{l}\text { Income } \\
\text { inequality }\end{array}$ & $\begin{array}{l}\text { Available } \\
\text { resources }\end{array}$ & $\begin{array}{l}\text { Local } \\
\text { competition }\end{array}$ & $\begin{array}{l}\text { Local } \\
\text { autonomy }\end{array}$ & $\begin{array}{l}\text { Regional } \\
\text { agency }\end{array}$ \\
\hline $\begin{array}{l}\text { Partnership } \\
\text { Combined Intergov't } \\
\text { Vertical Intergov’t } \\
\text { Horizontal Intergov’t } \\
\text { Public-Nonprofit } \\
\text { Public-Private } \\
\end{array}$ & $\begin{array}{l}+ \\
+ \\
+\end{array}$ & + & - & + & - & $\begin{array}{l}- \\
- \\
- \\
-\end{array}$ \\
\hline $\begin{array}{l}\text { Non-Partnership } \\
\text { Combined Intergov't } \\
\text { Vertical Intergov't } \\
\text { Horizontal Intergov't } \\
\text { Public-Nonprofit } \\
\text { Public-Private }\end{array}$ & $\begin{array}{l}- \\
- \\
-\end{array}$ & - & + & - & + & $\begin{array}{l}+ \\
+ \\
+ \\
+ \\
+\end{array}$ \\
\hline
\end{tabular}

Table 4. Ordinal Probit Results for Partnerships

\begin{tabular}{|l|l|l|l|l|l|}
\hline & $\begin{array}{l}\text { Combined } \\
\text { Intergov’t }+\end{array}$ & $\begin{array}{l}\text { Vertical } \\
\text { Intergov't+ }\end{array}$ & $\begin{array}{l}\text { Horizontal } \\
\text { Intergov't }+\end{array}$ & $\begin{array}{l}\text { Public- } \\
\text { Nonprofit* }\end{array}$ & $\begin{array}{l}\text { Public- } \\
\text { Private* }^{*}\end{array}$ \\
\hline Problem severity & $.031(.013)^{*}$ & $.026(.012)^{*}$ & $.028(.017)^{+}$ & $.026(.012)^{*}$ & $.027(.011)^{*}$ \\
Income inequality & $-.106(.362)$ & $-.196(.357)$ & $.105(.382)$ & $.321(.451)$ & $.031(.349)$ \\
Available resources & $-.006(.002)^{*}$ & $-.005(.002)^{*}$ & $-.002(.001)^{+}$ & $-.001(.002)$ & $-.002(.002)$ \\
Local competition & $.877(.498)^{+}$ & $1.226(.482)^{*}$ & $-.008(.655)$ & $.285(.610)$ & $.905(.634)$ \\
Local autonomy & $-.410(.213)+$ & $-.326(.213)$ & $-.283(.215)$ & $-.065(.217)$ & $.025(.198)$ \\
Regional agency & $-.165(.298)$ & $-.359(.326)$ & $.446(.372)$ & $-.104(.369)$ & $-.472(.383)$ \\
\hline Cut Point 1 & $-.530(2.110)$ & $-.210(1.813)$ & $-.072(2.216)$ & $1.374(2.245)$ & $.335(1.775)$ \\
Cut Point 2 & $.570(2.063)$ & $.086(1.823)$ & $.659(2.464)$ & $1.791(2.387)$ & $.753(1.797)$ \\
Cut Point 3 & $.904(2.061)$ & $.633(1.840)$ & $1.024(2.488)$ & $2.881(2.485)$ & $1.977(1.828)$ \\
Cut Point 4 & $1.365(2.076)$ & $1.271(1.850)$ & $2.416(2.538)$ & $4.030(2.539)$ & $2.779(1.839)$ \\
Cut Point 5 & $1.725(2.086)$ & - & - & - & - \\
Cut Point 6 & $2.227(2.104)$ & - & - & - & - \\
McFadden’s Pseudo R ${ }^{2}$ & .201 & .221 & .193 & .155 & .174 \\
Log likelihood & -103.356 & -83.775 & -62.095 & -79.507 & -86.529 \\
$\mathrm{~N}$ & 64 & 64 & 64 & 63 & 63 \\
\hline
\end{tabular}

Note: $+<.1, *<.05, * *<.01, * * *<.001$. Standard errors in parenthesis. 
This is an author-produced, peer-reviewed version of this article. The final, definitive version of this document can be found online at Journal for Critical Education Policy Studies, published by the Institute for Education Policy Studies. Copyright restrictions may apply.

Table 5. Ordinal Probit Results for Non-Partnerships

\begin{tabular}{|l|l|l|l|l|l|}
\hline & $\begin{array}{l}\text { Combined } \\
\text { Intergov't }+\end{array}$ & $\begin{array}{l}\text { Vertical } \\
\text { Intergov't+ }\end{array}$ & $\begin{array}{l}\text { Horizontal } \\
\text { Intergov't }+\end{array}$ & $\begin{array}{l}\text { Public- } \\
\text { Nonprofit* }\end{array}$ & Public-Private* \\
\hline Problem severity & $-.022(.011)^{*}$ & $-.023(.012)^{+}$ & $-.016(.012)$ & $.011(.010)$ & $-.008(.009)$ \\
Income inequality & $.124(.344)$ & $.026(.349)$ & $.193(.402)$ & $-.735(.357)^{*}$ & $-.360(.410)$ \\
Available resources & $.004(.001)^{* * *}$ & $.003(.001)^{*}$ & $.004(.002)^{*}$ & $.004(.002)^{*}$ & $.003(.002)^{+}$ \\
Local competition & $-1.237(.559)^{*}$ & $-1.306(.613)^{*}$ & $-1.027(.510)^{*}$ & $-.529(.580)$ & $-.642(.506)$ \\
Local autonomy & $.335(.180)^{+}$ & $.417(.178)^{*}$ & $.014(.244)$ & $.323(.215)$ & $.218(.241)$ \\
Regional & $.538(.345)$ & $.532(.388)$ & $.409(.373)$ & $.715(.343)^{*}$ & $.524(.302)^{+}$ \\
\hline Cut Point 1 & $-1.826(1.815)$ & $-2.312(1.948)$ & $-.032(2.100)$ & $-4.489(2.179)$ & $-3.393(2.253)$ \\
Cut Point 2 & $-1.545(1.781)$ & $-2.092(1.937)$ & $.791(2.119)$ & $-3.928(2.142)$ & $-2.738(2.224)$ \\
Cut Point 3 & $-1.284(1.782)$ & $-1.543(1.942)$ & $1.330(2.112)$ & $-2.700(2.098)$ & $-1.438(2.177)$ \\
Cut Point 4 & $-.835(1.784)$ & $-1.331(1.934)$ & - & $-1.672(2.065)$ & $-.510(2.221)$ \\
Cut Point 5 & $-.572(1.786)$ & $-.408(1.932)$ & - & - & - \\
Cut Point 6 & $-.084(1.765)$ & $-.121(1.920)$ & - & - & - \\
Cut Point 7 & $.324(1.764)$ & - & - & - & - \\
Cut Point 8 & $.798(1.808)$ & - & - & - & - \\
McFadden's Pseudo $\mathrm{R}^{2}$ & .189 & .184 & .186 & .209 & .170 \\
Log likelihood & -118.498 & -96.850 & -69.809 & -81.034 & -80.888 \\
$\mathrm{~N}$ & 64 & 64 & 64 & 63 & 63 \\
\hline
\end{tabular}

Note: $+<.1, *<.05, * *<.01, * * *<.001$. Standard errors in parenthesis.

Table 6. Summary of Statistically Significant Findings

\begin{tabular}{|c|c|c|c|c|c|c|}
\hline & $\begin{array}{l}\text { Problem } \\
\text { severity }\end{array}$ & $\begin{array}{l}\text { Income } \\
\text { inequality }\end{array}$ & $\begin{array}{l}\text { Available } \\
\text { resources }\end{array}$ & $\begin{array}{l}\text { Local } \\
\text { competition }\end{array}$ & $\begin{array}{l}\text { Local } \\
\text { autonomy }\end{array}$ & $\begin{array}{l}\text { Regional } \\
\text { agency }\end{array}$ \\
\hline $\begin{array}{l}\text { Partnership } \\
\text { Combined Intergov't } \\
\text { Vertical Intergov't } \\
\text { Horizontal Intergov't } \\
\text { Public-Nonprofit } \\
\text { Public-Private } \\
\end{array}$ & $\begin{array}{l}+ \\
+ \\
+ \\
+ \\
+ \\
\end{array}$ & & $\begin{array}{l}- \\
- \\
-\end{array}$ & $\begin{array}{l}+ \\
+\end{array}$ & 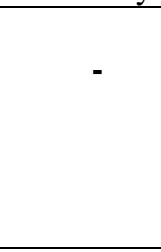 & \\
\hline $\begin{array}{l}\text { Non-Partnership } \\
\text { Combined Intergov't } \\
\text { Vertical Intergov't } \\
\text { Horizontal Intergov't } \\
\text { Public-Nonprofit } \\
\text { Public-Private }\end{array}$ & - & - & $\begin{array}{l}+ \\
+ \\
+ \\
+ \\
+\end{array}$ & $\begin{array}{l}- \\
- \\
-\end{array}$ & $\begin{array}{l}+ \\
+\end{array}$ & $\begin{array}{l}+ \\
+\end{array}$ \\
\hline
\end{tabular}


This is an author-produced, peer-reviewed version of this article. The final, definitive version of this document can be found online at Journal for Critical Education Policy Studies, published by the Institute for Education Policy Studies. Copyright restrictions may apply.

\section{Appendices}

\section{Appendix A. Variable Descriptive Statistics for Ordinal Probit Models}

\begin{tabular}{|c|c|c|c|c|c|}
\hline Variable & Description & Mean & $\begin{array}{l}\text { Std. } \\
\text { Dev. }\end{array}$ & Min & Max \\
\hline $\begin{array}{l}\text { Combined } \\
\text { intergovernmental } \\
\text { (partnership) }\end{array}$ & $\begin{array}{l}\text { Average of Likert scale response to positive partnership } \\
\text { survey item for local, state, and federal agencies }\end{array}$ & 4.37 & .63 & 3 & 5 \\
\hline $\begin{array}{l}\text { Vertical } \\
\text { intergovernmental } \\
\text { (partnership) }\end{array}$ & $\begin{array}{l}\text { Average of Likert scale response to positive partnership } \\
\text { survey item for state and federal agencies }\end{array}$ & 4.39 & .70 & 3 & 4 \\
\hline $\begin{array}{l}\text { Horizontal } \\
\text { intergovernmental } \\
\text { (partnership) }\end{array}$ & $\begin{array}{l}\text { Likert scale response to positive partnership survey item for } \\
\text { local agencies }\end{array}$ & 4.33 & .89 & 1 & 5 \\
\hline $\begin{array}{l}\text { Public-Nonprofit } \\
\text { (partnership) }\end{array}$ & $\begin{array}{l}\text { Likert scale response to positive partnership survey item for } \\
\text { nonprofit organizations }\end{array}$ & 3.79 & .99 & 1 & 5 \\
\hline $\begin{array}{l}\text { Public-Private } \\
\text { (partnership) }\end{array}$ & $\begin{array}{l}\text { Likert scale response to positive partnership survey item for } \\
\text { private organizations }\end{array}$ & 3.40 & 1.13 & 1 & 5 \\
\hline $\begin{array}{l}\text { Combined } \\
\text { intergovernmental } \\
\text { (non-partnership) }\end{array}$ & $\begin{array}{l}\text { Average of Likert scale response to negative partnership } \\
\text { survey item for local, state, and federal agencies }\end{array}$ & 1.86 & .84 & 1 & 4 \\
\hline $\begin{array}{l}\text { Vertical } \\
\text { intergovernmental } \\
\text { (non-partnership) }\end{array}$ & $\begin{array}{l}\text { Average of Likert scale response to negative partnership } \\
\text { survey item for state and federal agencies }\end{array}$ & 1.91 & .95 & 1 & 4 \\
\hline $\begin{array}{l}\text { Horizontal } \\
\text { intergovernmental } \\
\text { (non-partnership) }\end{array}$ & $\begin{array}{l}\text { Likert scale response to negative partnership survey item for } \\
\text { local agencies }\end{array}$ & 1.77 & .99 & 1 & 4 \\
\hline $\begin{array}{l}\text { Public-Nonprofit } \\
\text { (non-partnership) }\end{array}$ & $\begin{array}{l}\text { Likert scale response to negative partnership survey item for } \\
\text { nonprofit organizations }\end{array}$ & 2.49 & 1.13 & 1 & 5 \\
\hline $\begin{array}{l}\text { Public-Private (non- } \\
\text { partnership) }\end{array}$ & $\begin{array}{l}\text { Likert scale response to negative partnership survey item for } \\
\text { private organizations }\end{array}$ & 2.37 & 1.04 & 1 & 5 \\
\hline Problem severity & Annual median AQI (EPA 2018a) & 50.71 & 13.05 & 24 & 97 \\
\hline Available resources & $\begin{array}{l}\text { Rate of per capita spending per adjusted air quality index } \\
\text { point; calculated as (100-AQI)/spending per capita }\end{array}$ & 30.64 & 58.86 & .67 & 410.53 \\
\hline Income inequality & $\begin{array}{l}\text { Ratio of median household income in the } 20^{\text {th }} \text { percentile to } \\
\text { the } 80^{\text {th }} \text { percentile (US Census Bureau, 2018) }\end{array}$ & 5.55 & .46 & 4.20 & 6.93 \\
\hline Local competition & $\begin{array}{l}\text { Portion of metropolitan area population under agency } \\
\text { jurisdiction (US Bureau of Economic Analysis, 2018) }\end{array}$ & .63 & .34 & .01 & 1.00 \\
\hline Local autonomy & $\begin{array}{l}\text { Ordinal dummy variable comparing Dillon's Rule, modified } \\
\text { Dillon's Rule, and Home Rule states }\end{array}$ & 1.17 & .66 & 0 & 2 \\
\hline Regional & $\begin{array}{l}\text { Dummy variable comparing regional agencies with } \\
\text { city/county agencies }\end{array}$ & .38 & .49 & 0 & 1 \\
\hline
\end{tabular}

